The IMF's Annual Macroprudential Policy Survey-Objectives, Design, and Country Responses 


\title{
The IMF's Annual Macroprudential Policy Survey- Objectives, Design, and Country Responses
}

\author{
April 2018
}

\section{A. Introduction ${ }^{1}$}

Objectives. The IMF has started to construct a new macroprudential policy database based on a survey of its membership. ${ }^{2}$ The objective of the survey, which will be conducted every year, is to compile a global database cataloguing macroprudential measures taken by countries and over time. The first vintage of the database is now available, and records country responses received by the end of February 2018.

Macroprudential policy is still an evolving field, and the database will help inform policy makers about measures taken across the globe. Moreover, the database can be used by researchers in central banks, supervisory agencies, international organizations, and academia to conduct analysis of the impact of such measures within and across countries, thereby helping to generate further insights into the effectiveness of such measures in mitigating systemic risk. It is finally expected to help IMF staff because it will provide them with an additional source of information for bilateral country surveillance and multilateral analysis.

In addition to cataloguing macroprudential measures, the database provides the first global source of information on institutional arrangements supporting macroprudential policy across countries. Such information can be useful for countries that are still developing their own framework. It can also, over time, be used by researchers who want to investigate what kind of arrangements might be most conducive to macroprudential policy making, or what country-specific conditions may be associated with the choice of one type of framework over another.

The database is compiled exclusively from information provided by IMF member countries, that is, the database is "self-reported". Hence, a policy tool's inclusion in or absence from this database does not represent a judgment or decision by IMF staff or the IMF Board on whether a particular tool used by an IMF member is "macroprudential". Similarly, the database does not provide an assessment of the various institutional arrangements that are being reported by IMF member countries. Such classifications and assessments can instead be found in IMF staff reports and FSAP documents.

\footnotetext{
${ }^{1}$ This note was produced by an IMF staff team led by Erlend Nier (MCM) and including Chikako Baba, Salim M. Darbar, and Yi (Janice) Xue (all MCM). Comments and suggestions by the BIS (Ilhyock Shim) and FSB Secretariat (Costas Stephanou) are gratefully acknowledged.

2 This background note, prepared by IMF staff, does not necessarily reflect the views of the IMF Executive Board.
} 
Responses to the macroprudential policy survey are being made available online at www.imf.org, ensuring access to the detailed survey information for all interested researchers and policymakers worldwide.

Genesis. The global financial crisis (GFC) highlighted the need for dedicated macroprudential policy in safeguarding financial stability, and experience with macroprudential policy has been growing since then. Many countries have put in place dedicated institutional arrangements. As pointed out in (IMF-FSB-BIS 2016) progress is also being made with the design and implementation of macroprudential tools, and an increasing body of empirical research has been evaluating the effectiveness of macroprudential policy.

The IMF set out a framework to inform its advice on macroprudential policy in 2013 (IMF 2013) and elaborated this further in its IMF Staff Guidance Note on Macroprudential Policy (IMF 2014). A joint report by the IMF, FSB and BIS to the G20 in 2016 took stock of the experiences gained so far regarding elements and practices that can be useful for effective macroprudential policy making (IMF-FSB-BIS 2016)

While countries have been using macroprudential tools to mitigate systemic risk, in particularly since the GFC, there is currently no global and regularly updated database of such measures. Similarly, while many countries have introduced new or upgraded existing macroprudential institutional arrangements, no global source of information currently provides detail on these arrangements across countries.

Recognizing this gap, the IMF has, in consultation with the FSB and BIS, undertaken to develop a global macroprudential policy database, by leveraging its existing infrastructure and taking advantage of its near-global membership. G20 members welcomed this effort under the German Presidency at the March 18, 2017 meeting of Finance Ministers and Central Bank Governors in Baden Baden, and it was subsequently included in the G20 Leaders' Hamburg Action Plan of July 8, 2017. ${ }^{3}$

Along with the publication of the first vintage of the database in April 2018, this note provides information on the design of the survey and the data compilation, as well as descriptive statistics summarizing country responses on institutional arrangements and measures in use.

\section{B. Design and Process}

Design. The survey questionnaire was developed by IMF staff in consultation with the FSB and BIS. It asks countries to report measures that aim to contain systemic risk, in line with the definition of macroprudential policy as "the use of primarily prudential tools to limit systemic risk" (see further IMF 2013 and IMF-FSB-BIS 2016).

\footnotetext{
${ }^{3}$ The Baden Baden communique stated: "We also welcome the work of the IMF in consultation with the FSB and the Bank for International Settlements (BIS) to promote information sharing by compiling a publicly available macroprudential policy database, building on the IMF's existing infrastructure."
} 
The questionnaire also provides a detailed list of measures that are typically considered macroprudential and asks member countries to report for each tool whether it is in place (indicated with a "yes") or not in place ("no"). It then asks for further information on measures that are in place, including the date and year when the measure was introduced (and if applicable when removed), the scope of application of the measure, as well as further detail on the design and calibration of the measure. For example, where LTV limits are in place, jurisdictions are asked to provide detail on the caps applying to different types of loans.

The list of tools offered in the questionnaire is grouped under six broad categories that are associated with the different sources of systemic risk that are being mitigated by macroprudential measures. Following closely the discussion of measures in the IMF Staff Guidance Note on Macroprudential Policy_-Detailed Guidance on Instruments, these categories capture (1) tools applied to all (aggregate) exposures of the banking system ("broad-based tools"); (2) tools to address risks from banks' exposure to households ("household sector tools"); (3) tools to address risks from banks' exposure to nonfinancial firms ("corporate sector tools"); (4) tools to address liquidity risks and foreign exchange mismatches in the banking sector ("liquidity and foreign exchange tools"); (5) tools to address systemic liquidity risk and fire sale risk in the nonbank financial sector ("nonbank tools"); and (6) tools to address risks from systemically important institutions and interconnectedness within the financial system ("structural tools").

Under each of these headings, the survey lists a number of tools that were expected to be in use in IMF member countries; it also lists "other" as a possible entry, to allow countries to describe measures that are not included in the pre-set list, but that are still taken to mitigate systemic risks, or new measures whose design responds to the specific circumstances of the country.

In addition, the questionnaire requests information on the institutional aspects of the macroprudential policy framework, asking whether a macroprudential authority has been identified, the nature of the arrangement (committee or existing body), and the types of powers assigned to the macroprudential authority (as further detailed below).

Data process. The survey was sent to all IMF members during April-May 2017. It was sent along with an existing survey that supports the IMF's Annual Report on Exchange Arrangements and Exchange Restrictions (AREAER), in order to take advantage of the established processes for communication with IMF members.

For most countries, the survey was prepopulated by IMF staff with measures that were known from other IMF sources, such as those reported by countries in the context of the (one-off) 2013 Global Macroprudential Policy Instruments survey, so as to ease the burden for participating members. Upon receipt of the country submission, IMF staff communicated with responding country authorities, in order to improve the quality and completeness of submissions, and to seek to ensure some level of consistency across responses. Nevertheless, the information available in the database ultimately is self-reported by IMF member countries. 
In all, 141 (out of 192) jurisdictions responded to the survey. ${ }^{4}$ The level of detail provided in the responses varied across countries, ranging from detailed description of various macroprudential measures for a substantial number of countries, to a few countries indicating that most of the measures were not in place. A small number of countries included measures that the IMF would consider microprudential in nature (such as minimum capital requirements), while a few other countries were reluctant to provide information on the pre-set measures, since some of them were considered microprudential by the country authorities. ${ }^{5}$

For each country report, the changes in regulation during 2016 (and during 2017 where available) are reported in a separate "changes" table. While the reporting period for the first volume of the database is generally from January 1, 2016-December 31, 2016, information on developments in 2017 are also reported by many members. In addition, since this was the first year of reporting, respondents were requested to provide information starting from 2011 and to include any changes to the regulations since then where applicable. This information is available in the main table; however, such detailed information on all past changes were provided only by a fraction of countries. Going forward, members will be requested to update the changes table based on changes to regulation in the reporting year.

\section{Institutional Arrangements}

This is the first survey that aims to capture characteristics of national macroprudential institutional frameworks on a global scale. The survey asks respondents whether there is a designated macroprudential authority and whether that authority is vested in: (i) the central bank; (ii) a committee within the central bank; (iii) a committee or council outside the central bank; (iv) a supervisory agency (outside the central bank); or (v) whether the arrangements are characterized differently ("other"). It also asks whether an additional interagency coordinating body is part of the arrangements, and asks countries to provide further textual explanations, such as which agencies are represented on such committees.

The survey further asks respondents to indicate what type of powers are assigned to the macroprudential authority. In particular, following the taxonomy in IMF 2013, and IMF-FSB-BIS 2016, the survey asks whether it has "hard" powers (which give the macroprudential authority direct control over macroprudential instruments); "semi-hard" powers (enabling the macroprudential authority to make formal recommendations to other agencies, coupled with a "comply or explain" mechanism;

\footnotetext{
${ }^{4}$ In addition to the 189 IMF member countries, the survey was sent to Hong Kong SAR (China) as well as Aruba and Curaçao and Sint Maarten (all in the Kingdom of the Netherlands).

${ }^{5}$ For example, the survey takes the view that the Basel III capital conservation buffer (CCOB) is meant to provide a buffer of capital that banks can use to absorb losses before they hit microprudential constraints. This can reduce procyclicality of the capital framework and mitigate systemic risk. Likewise, the Liquidity Coverage Ratio (LCR) and Net Stable Funding Ratio (NSFR) are included among the list of measures since they can limit systemic liquidity risks arising from unstable funding structures. However, a few countries viewed these measures as more microprudential in nature.
} 
and "soft" powers (enabling the macroprudential authority to express an opinion or make a recommendation that is not subject to "comply or explain."

In all, 111 countries provided information on macroprudential institutional arrangements, while 30 reported that there was no macroprudential authority. A significant portion (45/111) of respondents indicated that a macroprudential mandate was assigned to more than one entity (e.g., both to the central bank and to an additional committee), indicating that institutional arrangements often involve multiple authorities within a jurisdiction (Table 1).

Most jurisdictions (80 out of 111) indicated that the central bank played an important role in macroprudential policy. Indeed, 39 countries (about 35 percent of all countries with a macroprudential authority) reported that the central bank is the sole macroprudential authority (Table 1). An additional ten reported that both the central bank and a committee within the central bank were being jointly responsible for macroprudential policy, while seven more (including the U.K.) reported that a committee within the central bank was the sole authority.

Nine countries (including France, India, and the U.S.) reported that a committee or council outside the central bank was the sole dedicated macroprudential authority, while such committees outside the central bank more commonly combined with one or more other agencies that were given macroprudential authority, such as the supervisory agency (as in Germany) or the central bank (as in China and the Netherlands), or both (as in Iceland).

Finally, only four countries reported a supervisory agency (other than the central bank) as being the sole macroprudential authority (Australia, Finland, Korea, and Sweden), even as these countries also report an additional coordinating body. More generally, additional interagency committees are common where a single agency (such as the central bank or the supervisory agency) is ultimately responsible for macroprudential policy.

The strength of powers assigned to the macroprudential authority appears to depend to some extent on the institutional set-up. The existence of hard powers was reported by 80 jurisdictions, where hard powers were assigned to a total of 91 bodies (committees or agencies). ${ }^{6}$ In 66 of these cases hard powers rested with the central bank or a committee within the central bank, while in only five cases a committee outside the central bank was assigned hard powers. Thirty-one jurisdictions reported semi-hard powers, of which just over a third (11) were reported by jurisdictions that indicated the macroprudential authority was vested in a committee outside the central bank. Soft powers were reported by over a quarter of the respondents (39 and vested in 42 authorities), but virtually all of these jurisdictions reported hard powers too.

The arrangements overall do not differ markedly across income groups. Central banks appear to play a lead role in both advanced economies (AEs) and emerging market and developing economies (EMDEs) (Figure 1), although AEs more frequently report that an outside supervisory agency, or a

\footnotetext{
${ }^{6}$ In some jurisdictions more than one authority is vested with powers.
} 
supervisory agency supported by a council was the macroprudential authority. Across regions, Asia and Pacific (APD) has the largest share of economies reporting a designated macroprudential authority, whereas Africa (AFR) has the lowest. ${ }^{7}$ Central banks appear to play strong roles in most regions, while countries in the Western Hemisphere (WHD) showed the lowest percentage of jurisdictions reporting that the central bank was one of the macroprudential authorities.

\section{Macroprudential Measures}

Overall, 141 countries reported a total of 1,313 macroprudential measures, for an average number of measures per country of 9.3. ${ }^{8}$ The use of macroprudential measures does not appear to differ much by income group, with the average number of measures at 9.9 for AEs and 9.1 for EMDEs.

Across the six categories of tools contained in the database, tools to manage liquidity and foreign exchange (FX) mismatches in the banking sector are most frequently reported globally, followed by tools to manage risks from exposures to the household sector, and broad-based tool applying to all exposures (Figure 2). Differences across income groups are also significant, with EMDEs making greater use of tools to manage liquidity and FX risks than AEs, and AEs more frequently employing tools aimed at exposures to the household sector, as well as tools to manage risks in the structural dimension and in the nonbank financial sector. Across regions, relatively more macroprudential measures are reported by countries in Asia and the Middle East, at an average of around 11 measures per country, while countries in Africa reported the lowest number (at an average of six measures per country), and countries in the Americas are at just over eight.

Broad-based tools. Among the broad-based tools, the capital conservation buffer (CCOB) is the most frequently used measure (in place in 76 countries) (Figure 3). The Basel III countercyclical capital buffer (CCyB) was activated with a positive rate in three jurisdictions (Sweden, Hong Kong SAR, and Norway) as of end-2016, and in three more jurisdictions (Slovak Republic, Czech Republic and Iceland) during 2017, with the UK also announcing a positive buffer rate for 2018. Although the number of countries with a positive buffer requirement therefore appears low, 73 economies reported that they had in place a CCyB framework, including 12 economies which introduced the framework during 2017.

The CCOB is more frequently used in Europe (EUR), compared to most other regions, reflecting the fact that this measure is required since early 2016 under the CRR/CRDIV framework of the European Union (EU). A leverage ratio cap has been introduced by 35 countries, and its use is expected to rise as the leverage ratio moves from a monitoring requirement to a limit under Basel III in 2018. Forward-looking loan loss provisioning requirements are tools that are being applied outside of the

\footnotetext{
${ }^{7}$ The regions reported in the paper are based on the five Area Departments of the IMF: African Department (AFR); Asia and Pacific Department (APD); European Department (EUR); Middle East and Central Asia Department (MCD); and Western Hemisphere Department (WHD).

${ }^{8}$ Measures refer to tools/instruments that are in place indicated by a "yes" response (i.e., action has been taken) across the various types of measures listed in the survey.
} 
Basel framework and are quite common in both the Western Hemisphere and in Asia. Broad-based caps on credit growth are also imposed in some countries, even as they are very rare in Europe (with Albania being the only country reporting this tool).

Household sector tools. Among the household sector tools, restrictions on loan-to-value (LTV) and debt-service-to-income (DSTI) ratios are the most frequently used globally (Figure 4). ${ }^{9}$ These tools are common in particular in Asia, Europe and the Middle East, with about half of the countries in these regions maintaining a restriction on the LTV ratio, while only around a quarter of countries in the Western Hemisphere reported this tool (Brazil and Canada amongst them). By contrast, tighter capital requirements on exposures to the household sector are commonly used across all regions (with the exception of Africa, where housing markets are less well developed on average), and including in the countries in the Western Hemisphere. For instance, Argentina applies a higher risk weight for loans at LTV ratio of above 75 percent. Other household sector tools, such as limits on amortization periods and restrictions on unsecured loans, are also common, and appear often to be used in combination with LTV and DSTI ratio caps in order to improve their effectiveness. For instance, of 39 countries that reported having a DSTI limit, 19 countries also impose limits on amortization periods.

Corporate sector tools. Compared to household sector tools, measures to manage risks from exposures to the corporate sector are much less commonly reported (Figure 5). The most frequently used ones are additional capital requirements on loans to the corporate sector (28 jurisdictions), which includes higher capital requirements for lending in FX. And caps on such lending in FX are also relatively common (used in 17 jurisdictions). Borrower-based measures are relatively less utilized, even as a cap on LTV ratios for commercial real estate credit is used by 12 jurisdictions. Some countries also limit lending to particular industries or sectors (14 jurisdictions).

Liquidity and FX tools. Tools to manage liquidity and FX mismatches in the banking system are the most frequently used macroprudential policy tools, with a wide variety of designs (Figure 6). A large number of countries (75 countries, about a half of respondents) reported that they maintain a net FX position limit in order to limit systemic risk. ${ }^{10} \mathrm{~A}$ large number of countries (74 countries) also reported that they imposed a Basel III liquidity coverage ratio (LCR), with this being particularly frequently reported in Europe, while other types of liquid asset ratio requirements are also used in the other regions. The Net Stable Funding Ratio (NSFR) is still much less frequently used (12 jurisdictions), reflecting that its rules in the Basel III framework were finalized only recently. Finally, many countries, especially in Central and South America, differentiate liquidity tools by currency, or maintain other constraints on FX funding.

Nonbank sector tools. Far fewer countries reported that they had in place tools to manage systemic liquidity and other systemic risks arising in the nonbank financial sector, with about a third of

\footnotetext{
${ }^{9}$ Restrictions on LTV, LTI, and DSTI ratios include both numerical caps on these ratios and exposure caps on loans with high ratios, as reported, for example, by New Zealand and the U.K.

10 The frequency of reporting of this tool is relatively low among European countries, where net open position limits are often implemented through the capital framework.
} 
respondents having some macroprudential rules in this area (Figure 7). As would have been expected, AEs used nonbank tools relatively more frequently, given their more developed financial markets. Across regions, Asian countries reported rules in the nonbank sector relatively frequently, while nonbank tools were infrequently used in Africa, likely indicating the lesser need for these measures.

Structural tools. Tools to address risks in the structural dimension most often take the form of additional capital surcharges for systemically important financial institutions (SIFIs), with limits (including large exposure limits) on the exposures between financial institutions also being frequently reported (Figure 8). SIFI surcharges are very common in Europe, with around 75 percent of European countries reporting the use of these surcharges (likely because "OSII buffers" are part of the CRD/CRDIV package in the EU), but are being implemented also quite actively in Asia, while (large) exposure limits for exposures between financial institutions are used equally frequently in all regions.

Recent Developments. Finally, based on the information provided, we can count the number of changes in macroprudential policy settings that became effective (or were announced) during the reporting period (Figure 9). When we focus on changes that became effective during January 1, 2016 to December 31, 2016, most countries reported at least one change in macroprudential settings. Activity was strongest in Europe, where there were more than three changes per country on average, followed by Asia and Pacific with just over two changes per country on average. Across all tools, the overwhelming majority of all changes amounted to a tightening of macroprudential measures, even if easing is also observed. Liquidity tools were most frequently modified, and a total of 87 tightening changes became effective in 2016, reflecting in part a phase-in of the LCR. More generally, a sizable fraction of tightening measures reflects the phasing-in or other adjustments of Basel measures, also including the CCOB. Many tightening changes in broad-based tools (54 instances) and household sector tools (43 instances) also became effective in 2016.

\section{E. Conclusion and Next Steps}

The macroprudential policy database will be updated on an annual basis, and the next cycle will start in April 2018, with the survey being sent out to all country authorities once again. This second round will allow country authorities to review their responses, in light also of responses by other countries, and record changes in macroprudential policy settings that occurred over the period January 2017 to December 2017.

As this process continues, and with experience being accumulated in responding to the survey, IMF staff hope that participation in the survey, as well as the consistency and quality of responses should further improve. Moreover, since the database will be maintained indefinitely, it will, over time, generate reliable time series information of macroprudential policy actions across the IMF membership, making the database even more useful for research and policy purposes.

IMF staff would like to express their appreciation to the authorities of member countries for their invaluable input and to the G20 for their support for this important initiative. 


\begin{tabular}{|c|c|c|c|c|c|}
\hline $\begin{array}{l}\text { Number of } \\
\text { Authorities }\end{array}$ & Central Bank (CB) & $\begin{array}{l}\text { Committee } \\
\text { Within a CB }\end{array}$ & $\begin{array}{l}\text { Committee } \\
\text { Outside CB }\end{array}$ & $\begin{array}{c}\text { Supervisory } \\
\text { Agency }\end{array}$ & Other \\
\hline One & $\begin{array}{l}\text { Armenia, Bahrain, Belgium, Belize, } \\
\text { Bhutan, Cambodia, Chile, Curaçao } \\
\text { and Sint Maarten, Cyprus, Czech } \\
\text { Republic, Djibouti, Estonia, Ghana, } \\
\text { Greece, Guatemala, Hong Kong SAR, } \\
\text { ndonesia, Ireland, Kazakhstan, } \\
\text { Kosovo, Lesotho, Lithuania, } \\
\text { Macedonia, Maldives, Malta, } \\
\text { Myanmar, Nepal, New Zealand, } \\
\text { Pman, Papua New Guinea, Portugal, } \\
\text { Qatar, Russia, Rwanda, Sierra Leone, } \\
\text { Slovak Republic, Sri Lanka, Ukraine, } \\
\text { Zambia }\end{array}$ & $\begin{array}{l}\text { El Salvador, } \\
\text { Guyana, Hungary, } \\
\text { Israel, Tajikistan, } \\
\text { Tunisia, United } \\
\text { Kingdom }\end{array}$ & $\begin{array}{l}\text { France, India, } \\
\text { Luxembourg, } \\
\text { Morocco, } \\
\text { Poland, } \\
\text { Romania, } \\
\text { Slovenia, } \\
\text { United States, } \\
\text { Vanuatu }\end{array}$ & $\begin{array}{l}\text { Australia, } \\
\text { Finland, Korea, } \\
\text { Sweden }\end{array}$ & $\begin{array}{l}\text { Belarus, } \\
\text { Brazil, } \\
\text { Pominican } \\
\text { Republic, } \\
\text { Norway, Peru, } \\
\text { Spain, Tuvalu }\end{array}$ \\
\hline Subtotal & 39 & 7 & 9 & 4 & 7 \\
\hline Two & $\begin{array}{l}\text { Albania, Argentina, Bangladesh, } \\
\text { Botswana, Brunei Darussalam, China, } \\
\text { Costa Rica, Egypt, Georgia, Italy, } \\
\text { Jamaica, Japan, Jordan, Kyrgyz } \\
\text { Republic, Liberia, Malaysia, } \\
\text { Mauritius, Mongolia, Netherlands, } \\
\text { Philippines, Serbia, Singapore, South } \\
\text { Africa, Thailand, Venezuela, Vietnam }\end{array}$ & $\begin{array}{l}\text { Brunei } \\
\text { Darussalam, } \\
\text { Georgia, Jamaica, } \\
\text { Jordan, Liberia, } \\
\text { Malaysia, } \\
\text { Singapore, South } \\
\text { Africa, Thailand, } \\
\text { Vietnam }\end{array}$ & $\begin{array}{l}\text { Albania, } \\
\text { Austria, Bolivia, } \\
\text { China, Egypt, } \\
\text { Germany, } \\
\text { Mauritius, } \\
\text { Mongolia, } \\
\text { Philippines, } \\
\text { Serbia, } \\
\text { Venezuela }\end{array}$ & $\begin{array}{l}\text { Austria, Bolivia, } \\
\text { Botswana, Costa } \\
\text { Rica, Germany, } \\
\text { lapan, Kyrgyz } \\
\text { Republic }\end{array}$ & $\begin{array}{l}\text { Argentina, } \\
\text { Bangladesh, } \\
\text { taly, } \\
\text { Netherlands }\end{array}$ \\
\hline Subtotal & 26 & 10 & 11 & 7 & 4 \\
\hline Three & $\begin{array}{l}\text { Bulgaria, Cabo Verde, Croatia, } \\
\text { Honduras, Iceland, Latvia, Lebanon, } \\
\text { Switzerland, Tanzania, Uruguay }\end{array}$ & $\begin{array}{l}\text { Cabo Verde, } \\
\text { Lebanon, } \\
\text { Tanzania, Uruguay }\end{array}$ & $\begin{array}{l}\text { Cabo Verde, } \\
\text { Croatia, } \\
\text { Denmark, } \\
\text { celand, Latvia, } \\
\text { Tanzania, } \\
\text { Uruguay }\end{array}$ & $\begin{array}{l}\text { Bulgaria, } \\
\text { Croatia, } \\
\text { Denmark, } \\
\text { Honduras, } \\
\text { celand, Latvia, } \\
\text { Lebanon, } \\
\text { Switzerland }\end{array}$ & $\begin{array}{l}\text { Bulgaria, } \\
\text { Denmark, } \\
\text { Honduras, } \\
\text { Switzerland }\end{array}$ \\
\hline Subtotal & 10 & 4 & 7 & 8 & 4 \\
\hline Four & $\begin{array}{l}\text { Angola, Mexico, Nigeria, Pakistan, } \\
\text { Saudi Arabia }\end{array}$ & $\begin{array}{l}\text { Angola, Nigeria, } \\
\text { Pakistan, Saudi } \\
\text { Arabia }\end{array}$ & $\begin{array}{l}\text { Mexico, } \\
\text { Nigeria, } \\
\text { Pakistan, Saudi } \\
\text { Arabia }\end{array}$ & $\begin{array}{l}\text { Angola, } \\
\text { Mexico, Nigeria, } \\
\text { Pakistan }\end{array}$ & $\begin{array}{l}\text { Angola, } \\
\text { Mexico, Saudi } \\
\text { Arabia }\end{array}$ \\
\hline Subtotal & 5 & 4 & 4 & 4 & 3 \\
\hline Total & 80 & 25 & 31 & 23 & 18 \\
\hline
\end{tabular}

Source: IMF Macroprudential Policy Database. 
Figure 1a. Macroprudential Authority

- Central bank

Committee within the CB 1/

- Committee outside the CB 2/

Supervisory agency

- Committee outside the CB \& supervisory agency 3 /

" Multiple authorities 4/

EOther authority

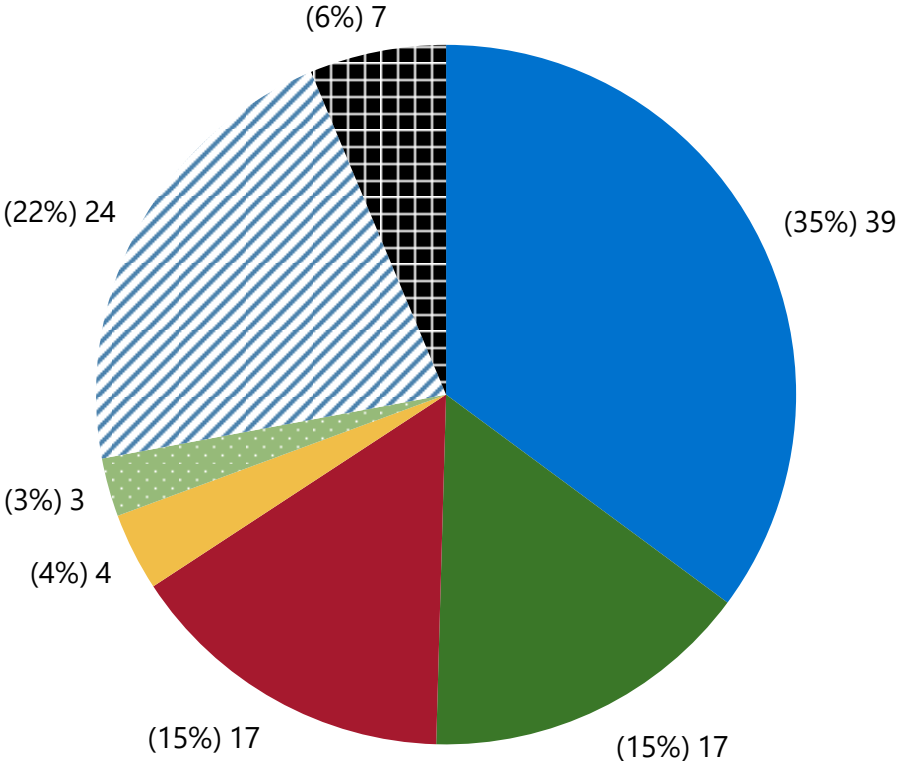

(15\%) 17

$1 /$ Includes jurisdictions reporting a committee within the Central Bank as the sole authority or jointly with central bank. 2 / Includes jurisdictions reporting a committee outside the Central Bank as the sole authority or jointly with central bank. $3 /$ Includes jurisdictions reporting both committee and supervisory agency as macroprudential authorities.

4/ Includes jurisdictions reporting at least two macroprudential authorities that are different from above mentioned.

\section{Frequency of Institutional Setup}

(In percent of reporting countries)

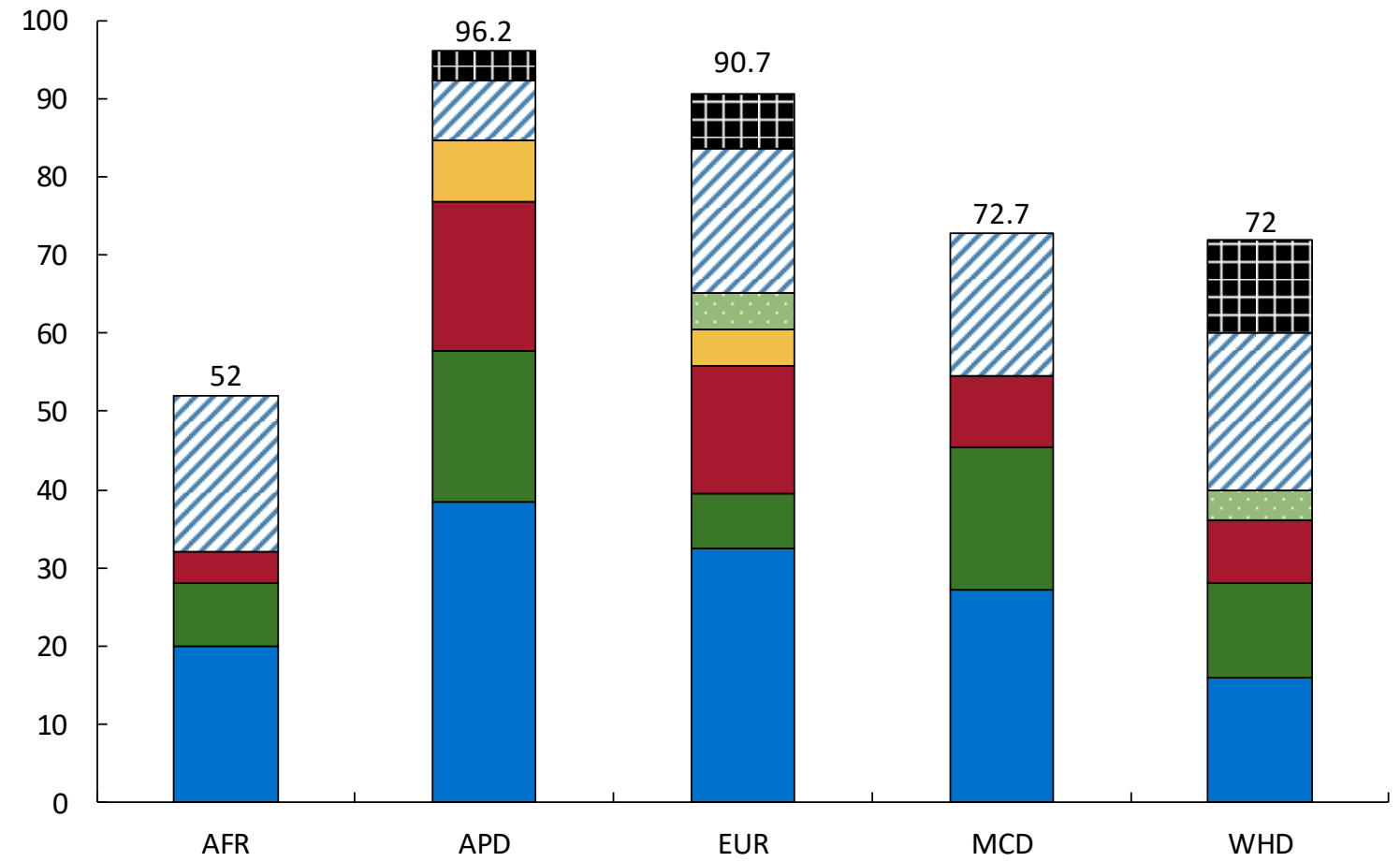

Sources: IMF Macroprudential Policy Survey, IMF staff estimates. 
Figure $1 \mathrm{~b}$. Macroprudential Authority

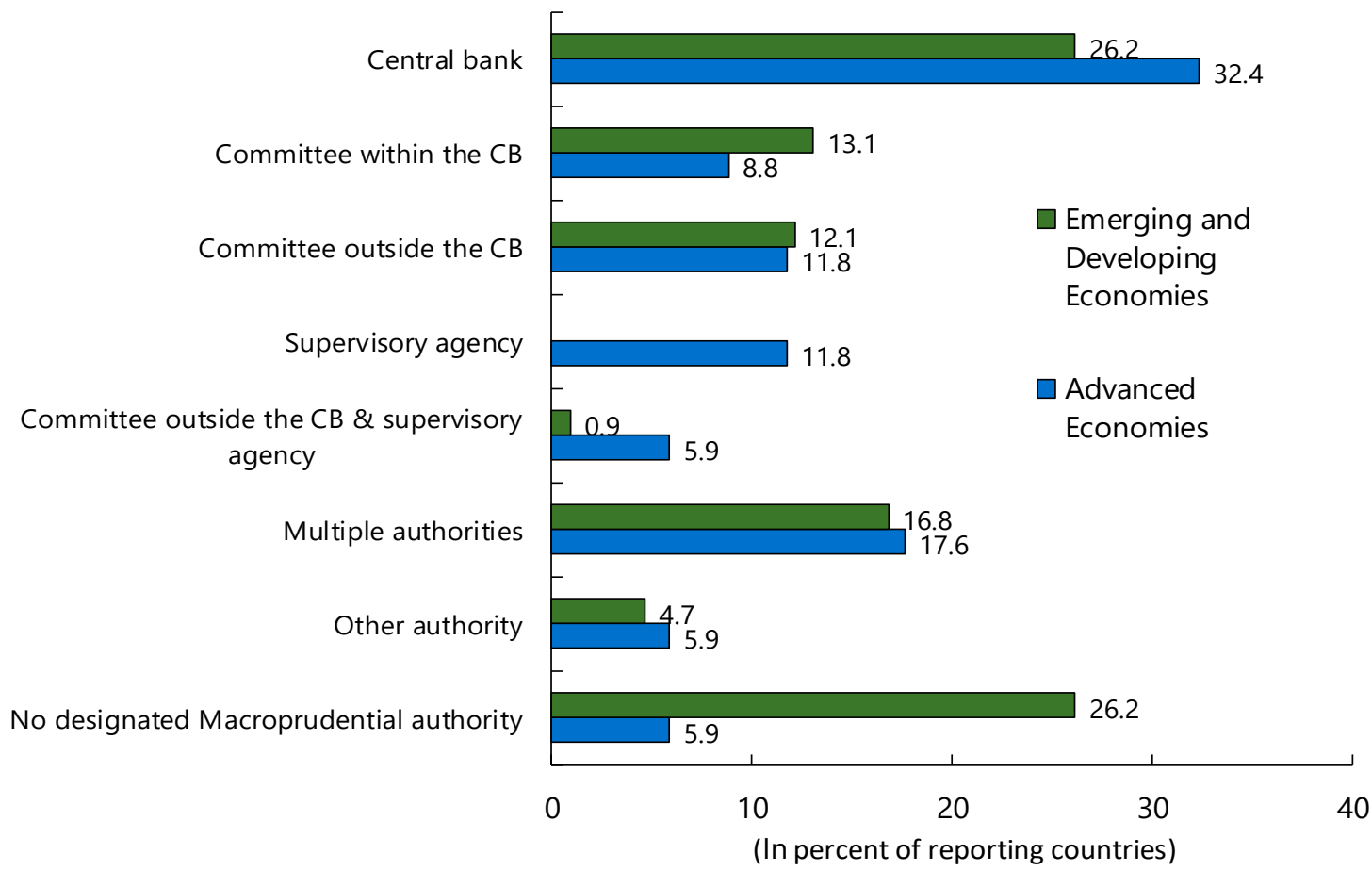

Macroprudential Authority's Powers

(Number of agencies)

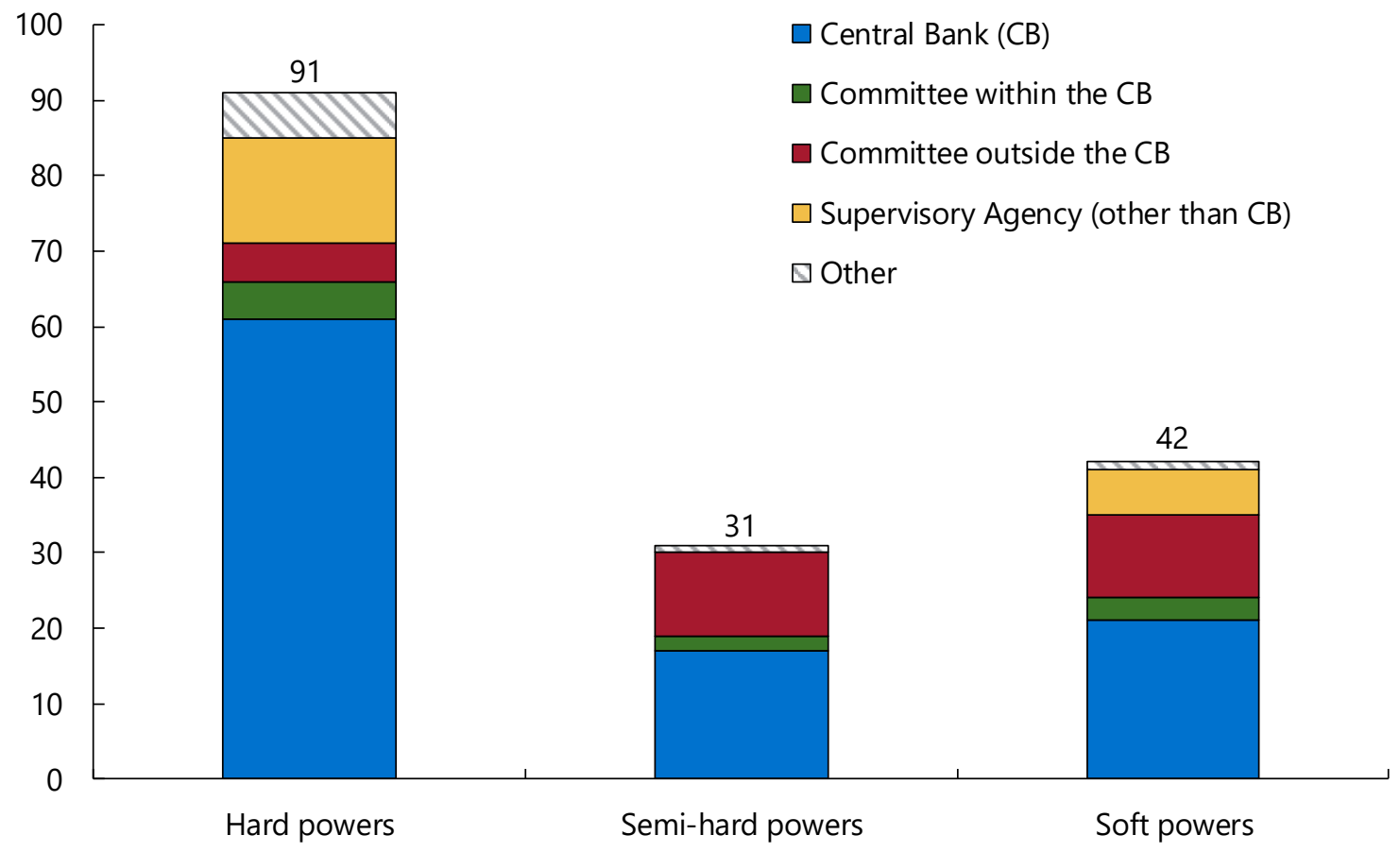

Sources: IMF Macroprudential Policy Survey, IMF staff estimates. 
Figure 2. Macroprudential Tools

\section{All Countries}

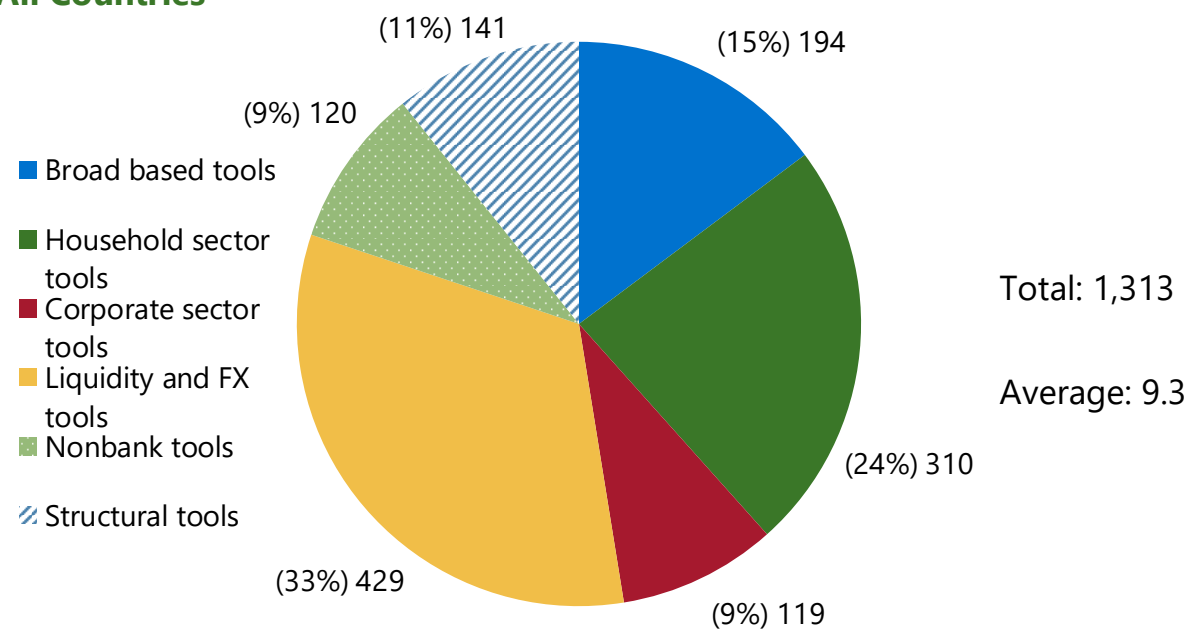

Advanced Economies

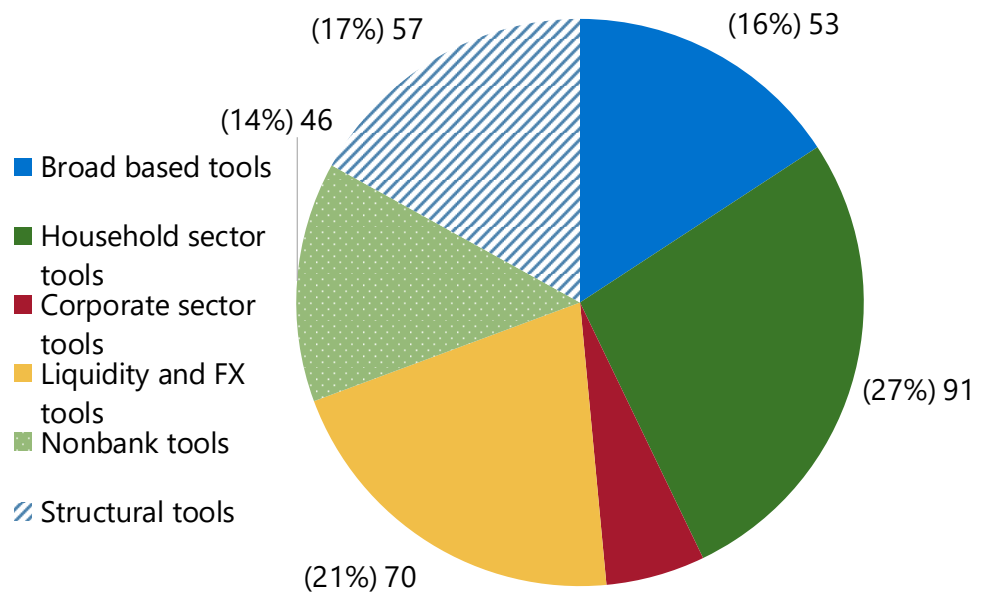

Total: 336

Average: 9.9

(6\%) 19

\section{Emerging and Developing Economies}

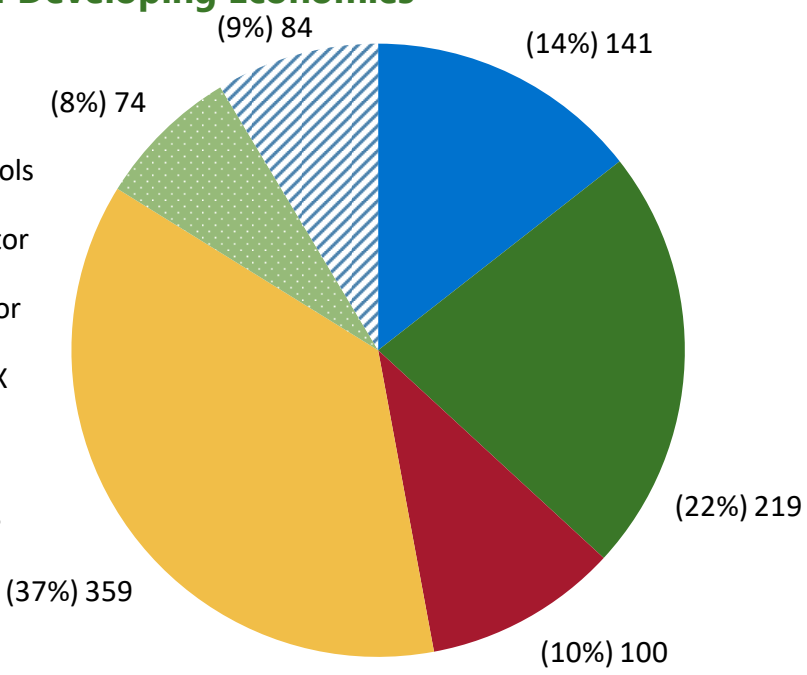

Total: 977

tools

- Corporate secto

tools

Liquidity and FX

tools

Nonbank tools

Structural tools

Average: 9.1

Source: IMF Macroprudential Policy Survey 
Figure 3. Broad Based Tools

\section{Number of Broad based Tools 1/}

- Capital conservation buffer

- Limit on leverage ratio

- Forward-looking loan loss

(5\%) 9 (19\%) 37 provisioning requirement

Cap on credit growth

- Countercyclical capital buffer

r. Other tools

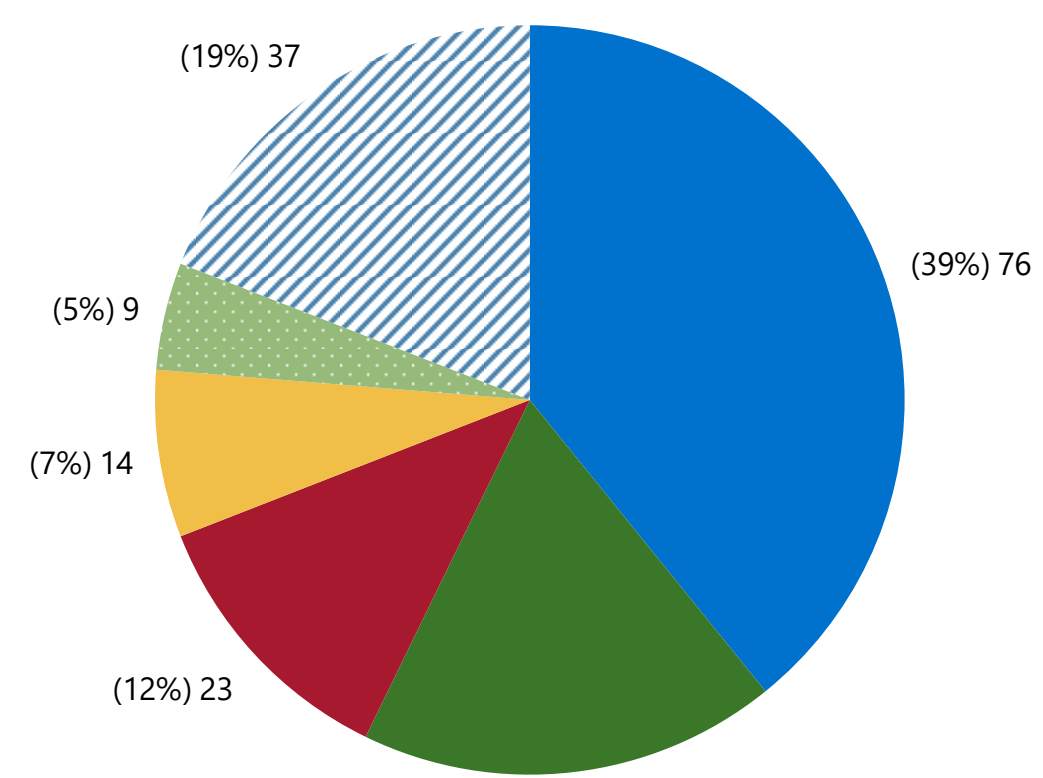

(18\%) 35

1/Numbers denote frequency of measures reported; percentages denote the share among total measures reported.

\section{Average Number of Measures}

(Per country)

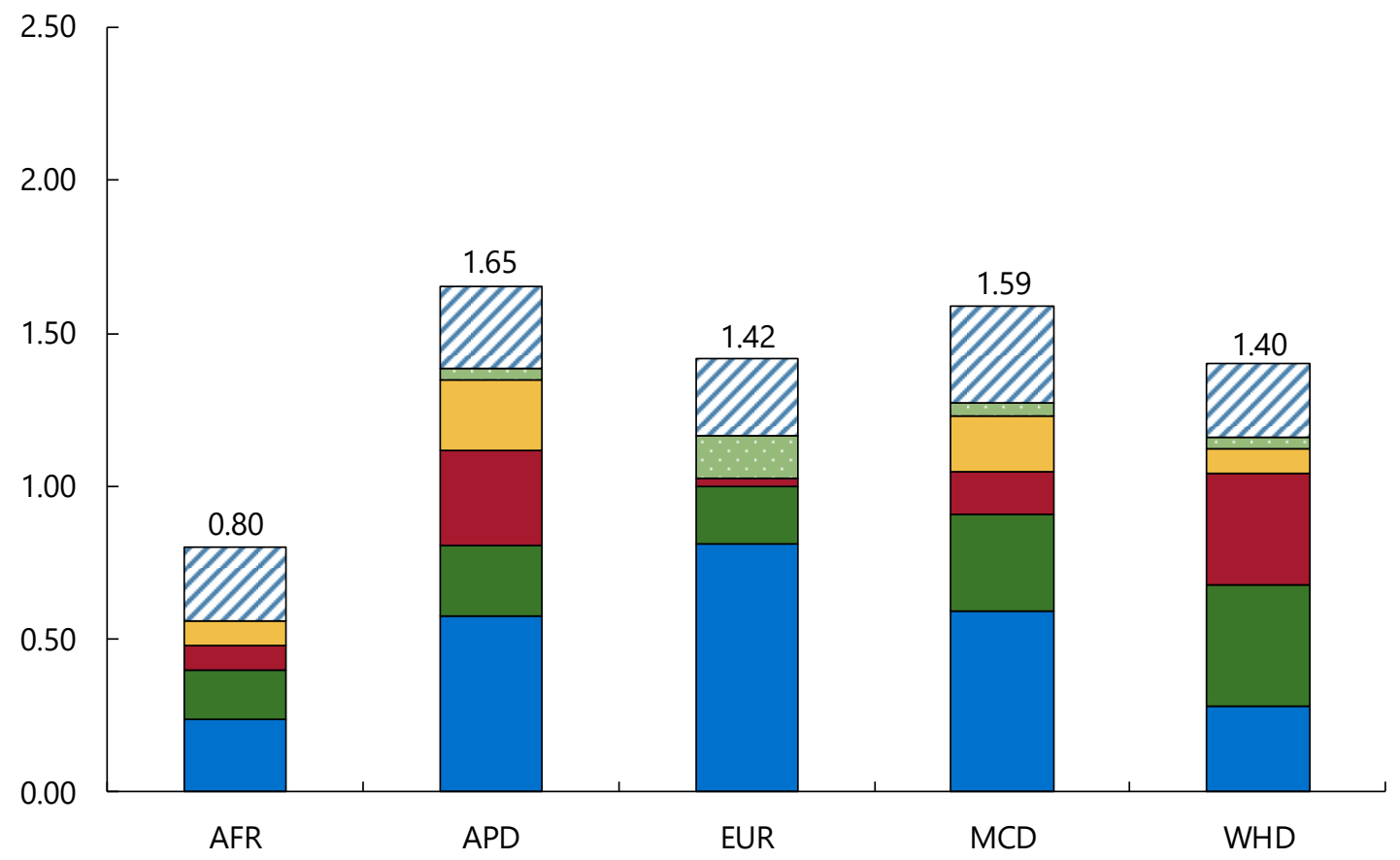

Source: IMF Macroprudential Policy Survey. 
Figure 4. Household Sector Tools

\section{Number of Household Sector Tools 1/}

- Restrictions on loan-to-value ratio

- Restrictions on debt-serviceto-income ratio

- Household sector capital requirements

Restrictions on unsecured loans

- Limit on amortization periods

¿ Cap on foreign-currencydenominated loans

- Restrictions on loan-to-income ratio

" Cap on credit growth to the household sector

$\neg$ Fiscal measures to contain systemic risks

Others

(3\%) 8

(4\%) 12

(4\%) 13

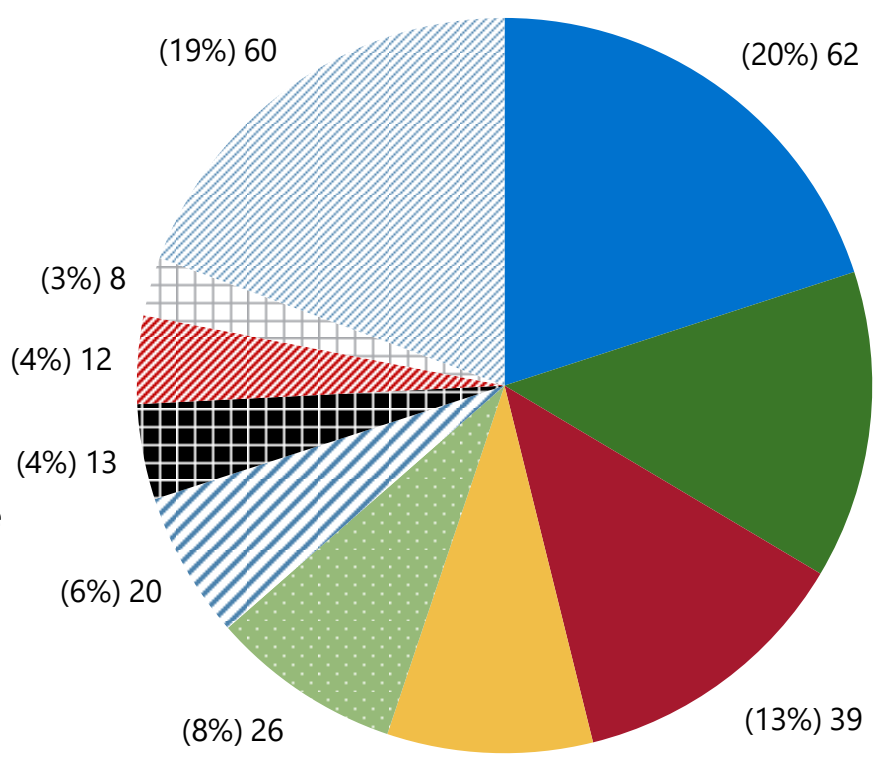

(9\%) 28

$1 /$ Numbers denote frequency of measures reported; percentages denote the share among total measures reported.

\section{Average Number of Measures}

(Per Country)

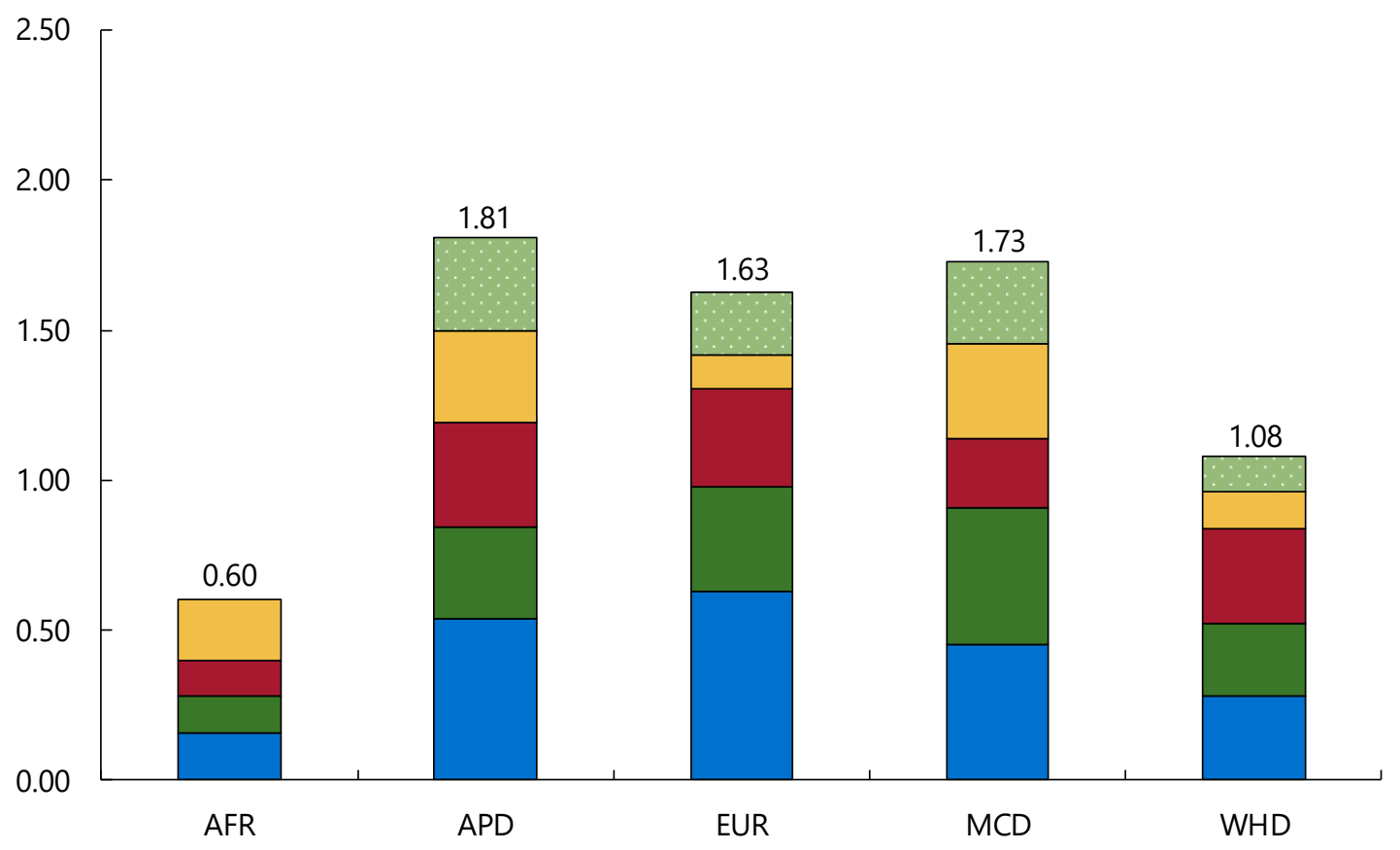

Source: IMF Macroprudential Policy Survey. 
Figure 5. Corporate Sector Tools

Number of Corporate Sector Tools 1/

- Corporate sector capital requirements

- Cap on foreign-currencydenominated loans

- Cap on Lending to particular industries or sectors

- Cap on loan-to-value ratio for commercial real estate credit

- Cap on credit growth to the corporate sector

" others

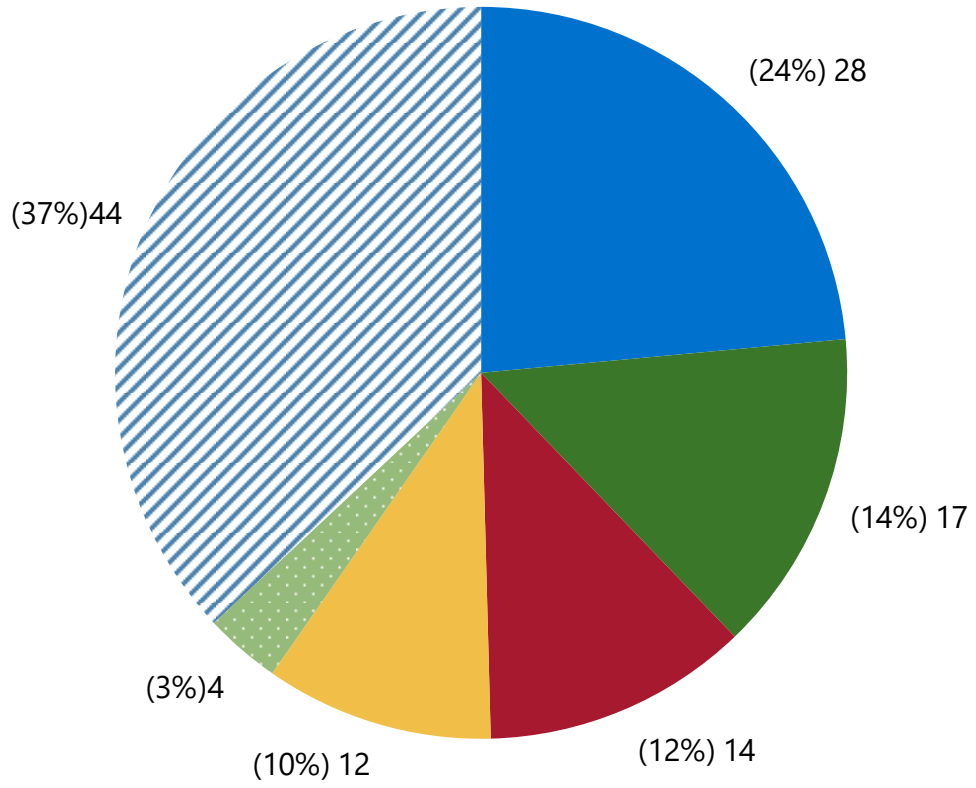

$1 /$ Numbers denote frequency of measures reported; percentages denote the share among total measures reported.

\section{Average Number of Measures}

(Per country)

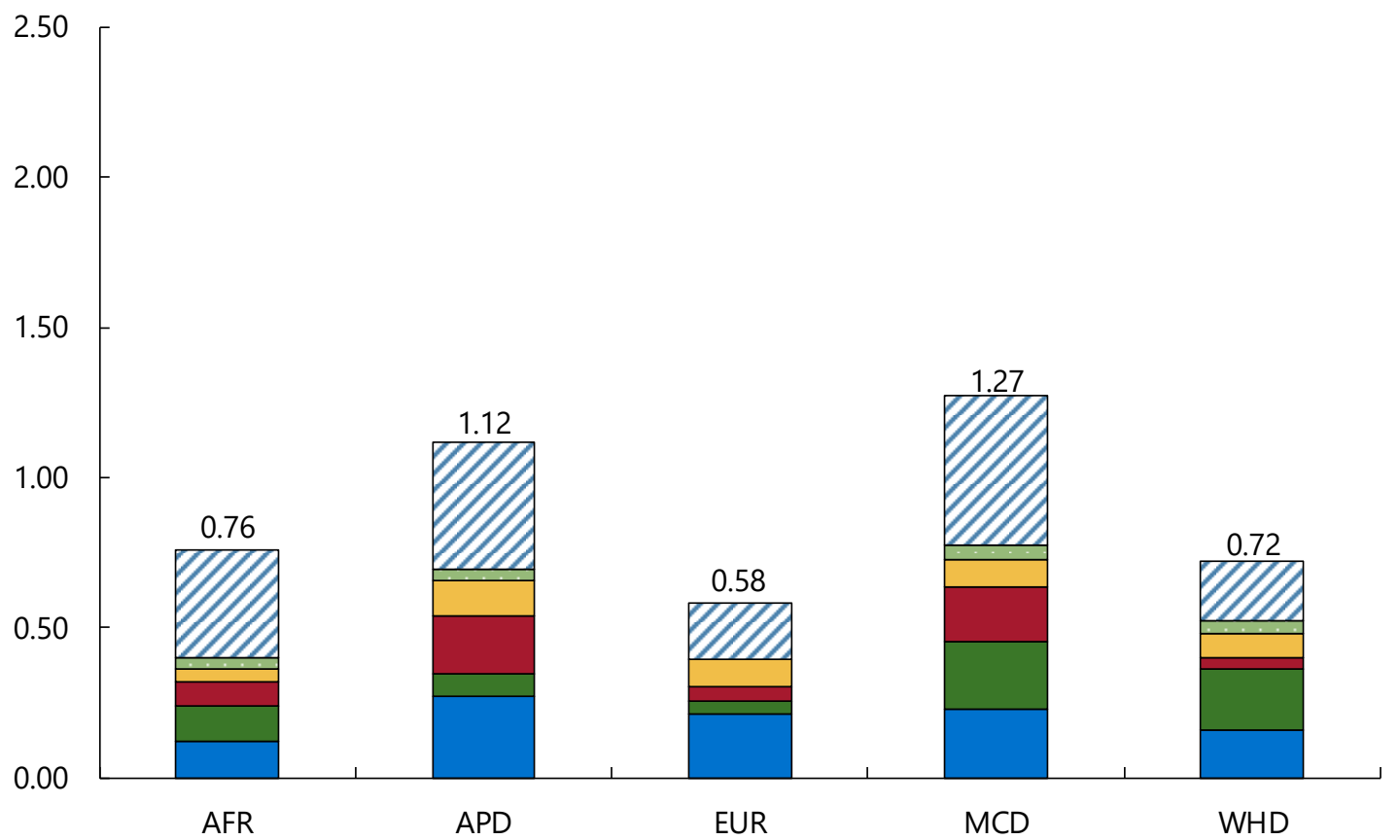

Source: IMF Macroprudential Policy Survey. 
Figure 6. Liquidity and FX Tools

\section{Number of Liquidity and FX Tools 1/}

- Net foreign exchange positions

- Liquidity Coverage Ratio

- Liquid asset ratio

Reserve requirements

Foreign exchange swaps or derivative positions

\%. Liquidity Coverage Ratio differentiated by currency

ii Constraints on foreign exchange funding

\% Loan-to-deposit ratio

(3\%) 12

(4\%) 16

(4\%) 17

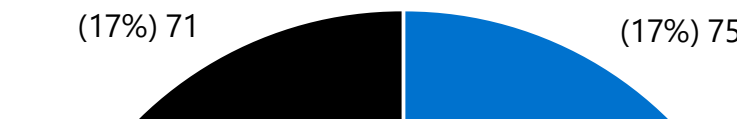

$T$ Reserve requirements and levies differentiated by currency

" Liquid asset ratio differentiated by currency

. Net Stable Funding Ratio

(3\%) 12

(5\%) 23

(6\%) 24

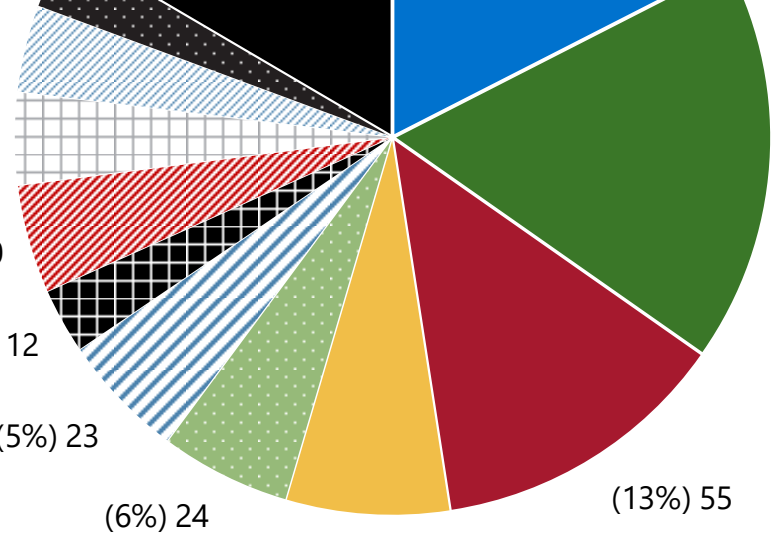

$(17 \%) 74$

Others

(7\%) 30

1/Numbers denote frequency of measures reported; percentages denote the share among total measures reported.

\section{Average Number of Measures}

(Per country)

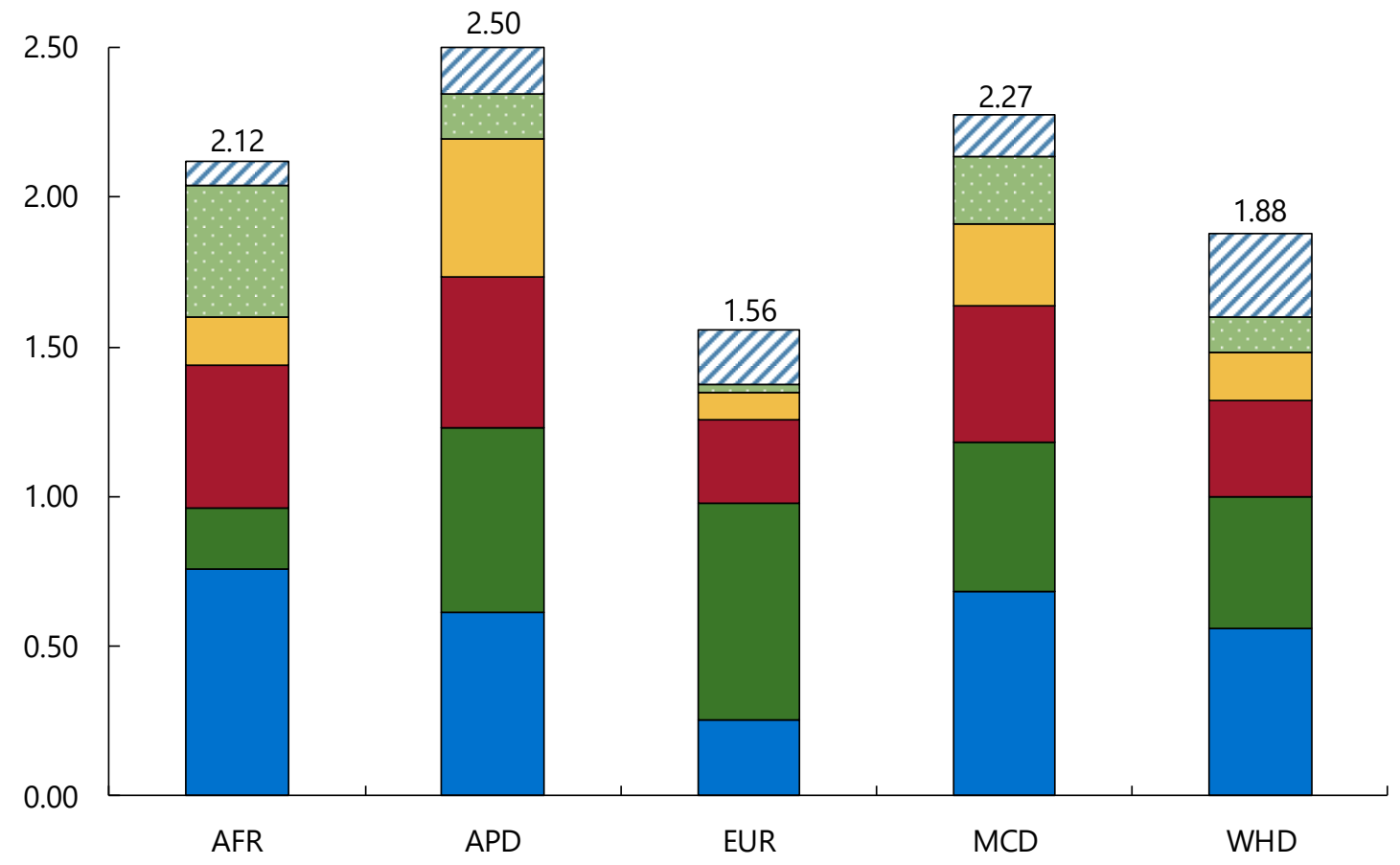

Source: IMF Macroprudential Policy Survey. 
Figure 7. Nonbank Tools

Number of Nonbank Tools $1 /$

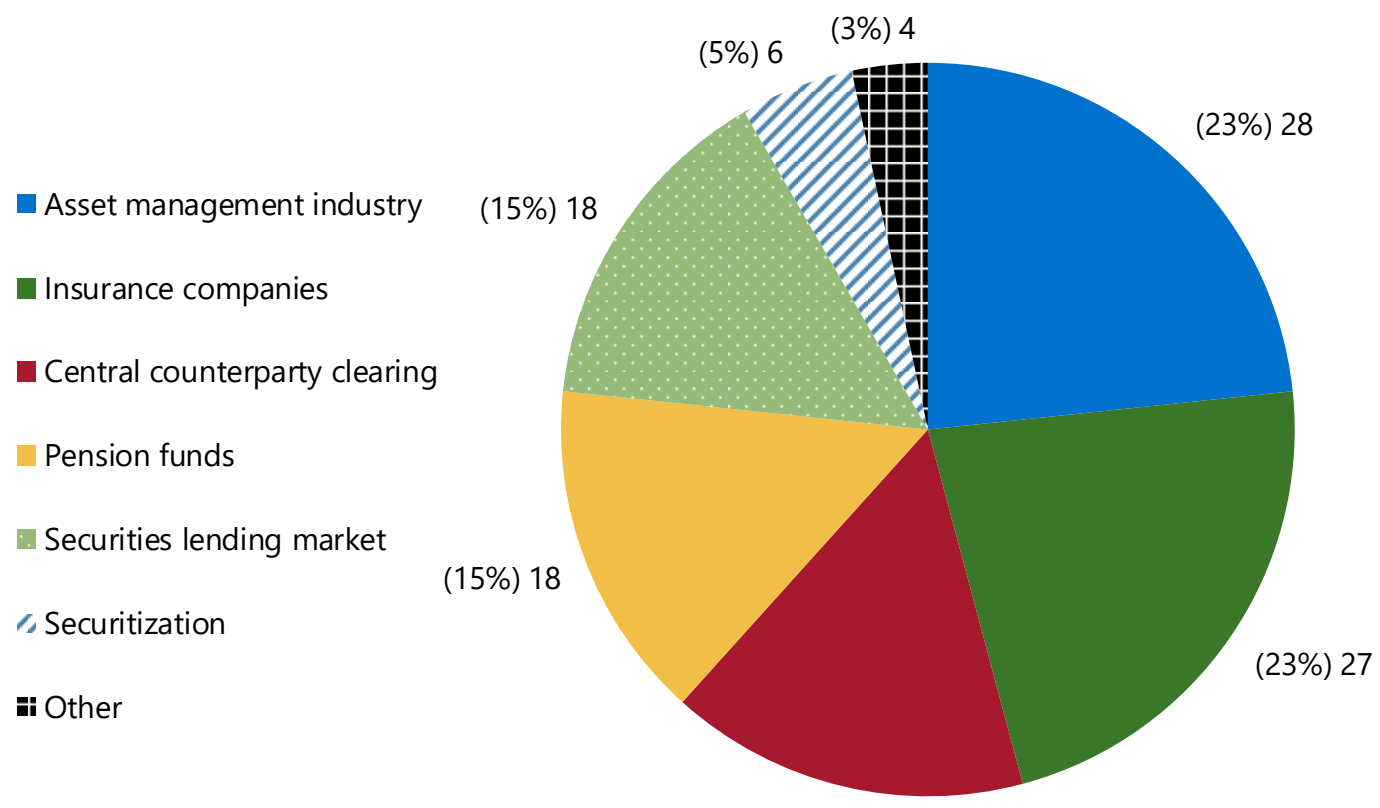

(16\%) 19

$1 /$ Numbers denote frequency of measures reported; percentages denote the share among total measures reported.

\section{Average Number of Measures}

(Per country)

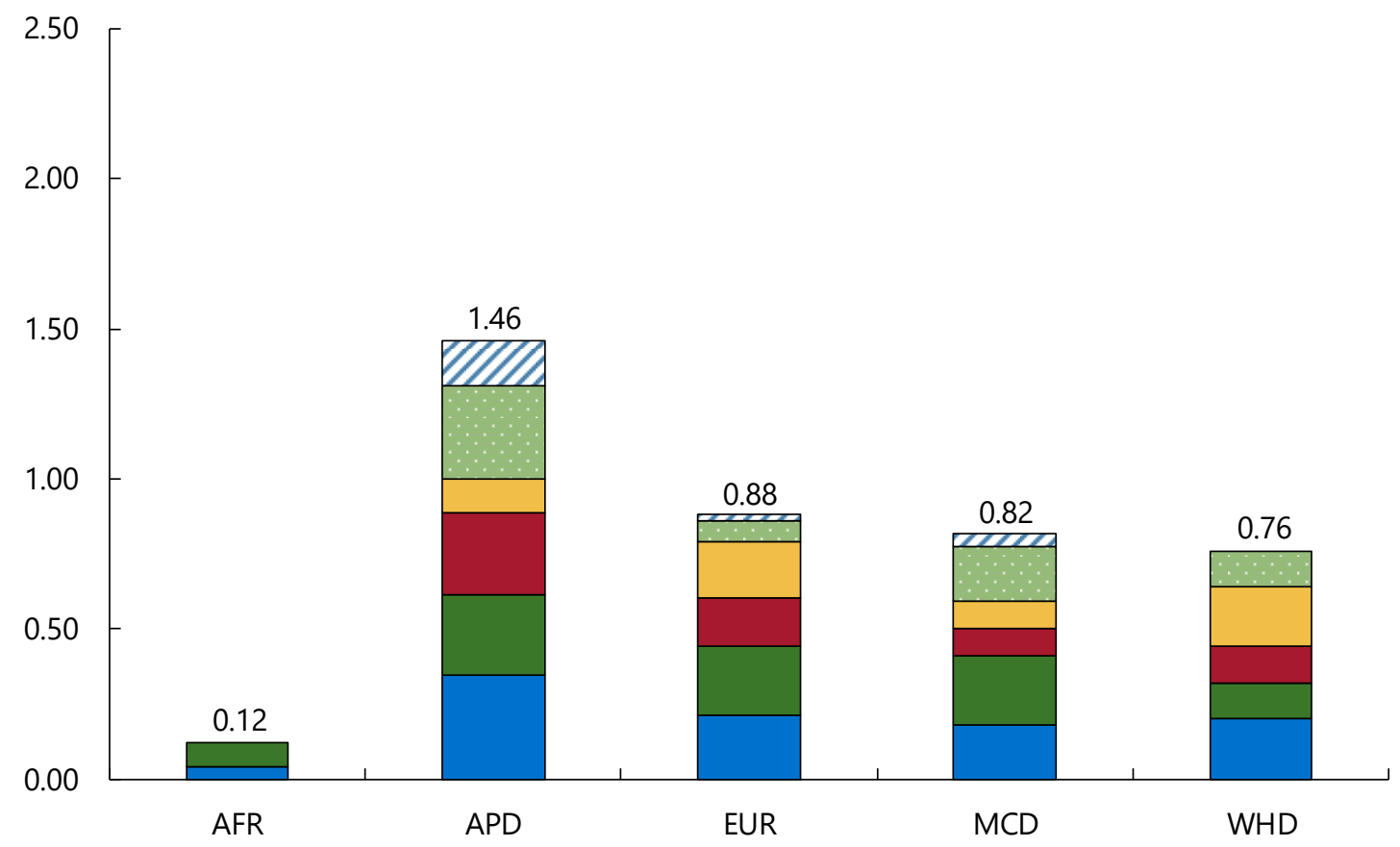

Source: IMF Macroprudential Policy Survey. 
Figure 8. Structural Tools

Number of Structural Tools 1/

- Capital surcharges for systemically important institutions

- Limits on the size of exposures between financial institutions

(6\%) 8

(23\%) 32

Additional risk weights on exposures between financial institutions

Others

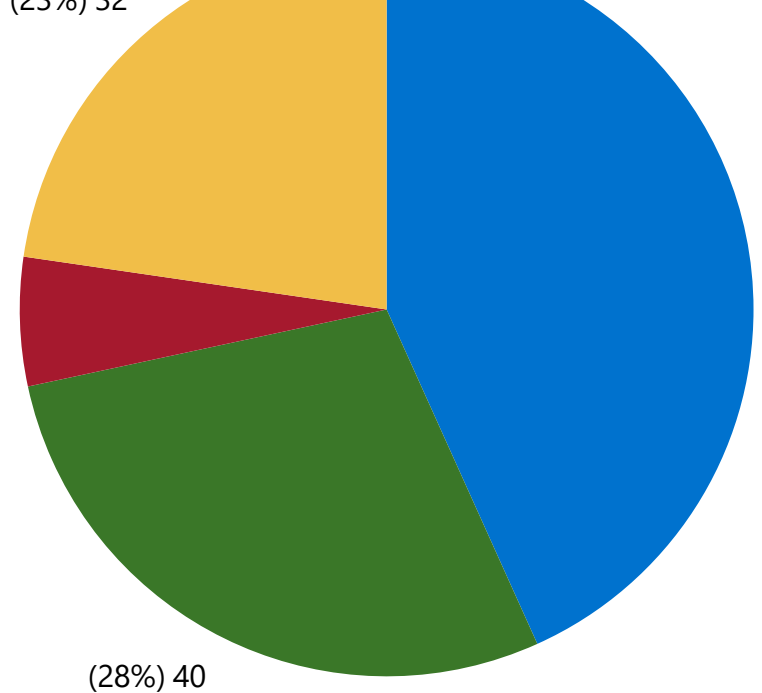

(43\%) 61

$1 /$ Numbers denote frequency of measures reported; percentages denote the share among total measures reported.

\section{Average Number of Measures}

(Per country)

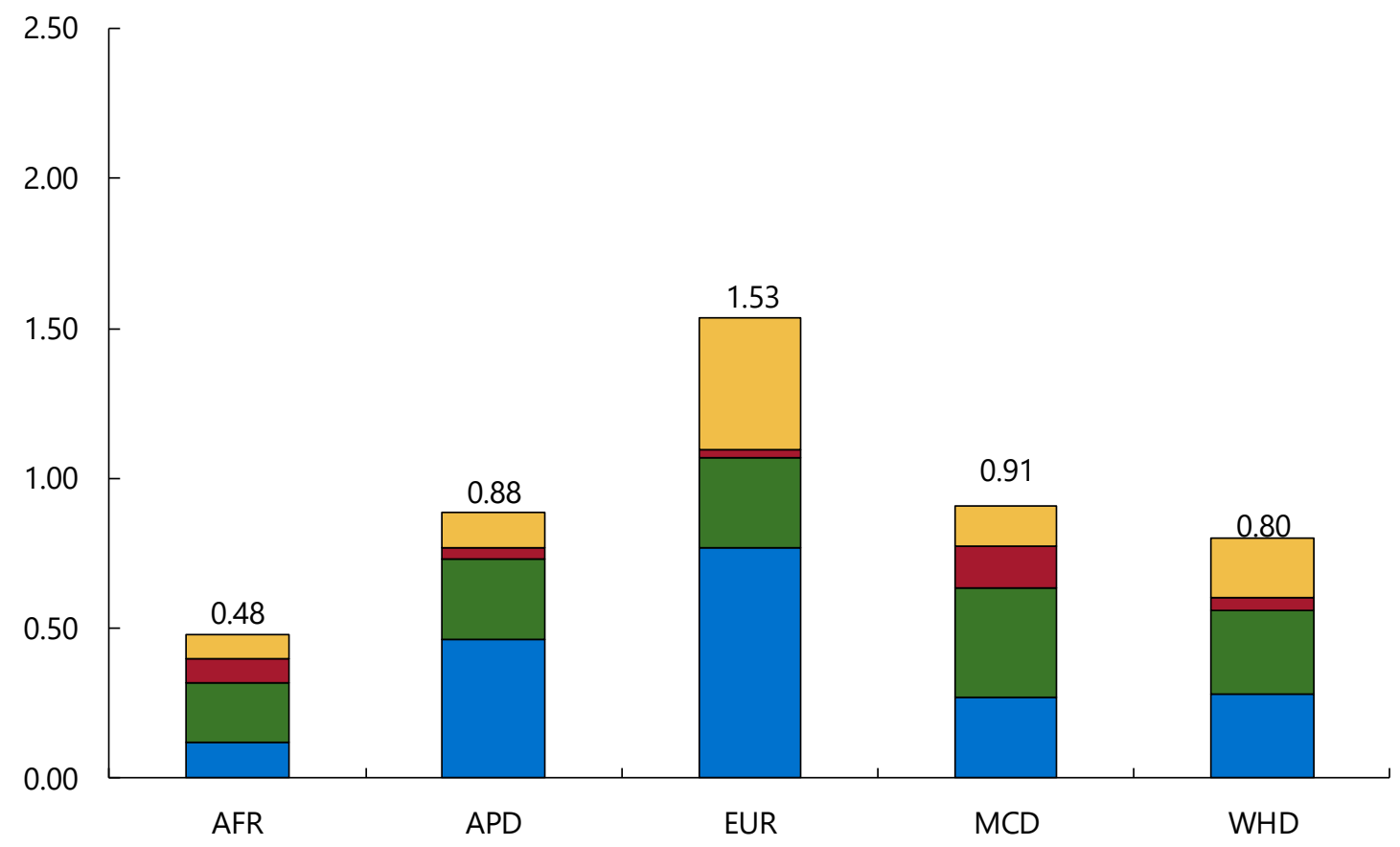

Source: IMF Macroprudential Policy Survey. 
Figure 9. Changes of Macroprudential Tools During 2016

Average Number of Changes

(Per country)

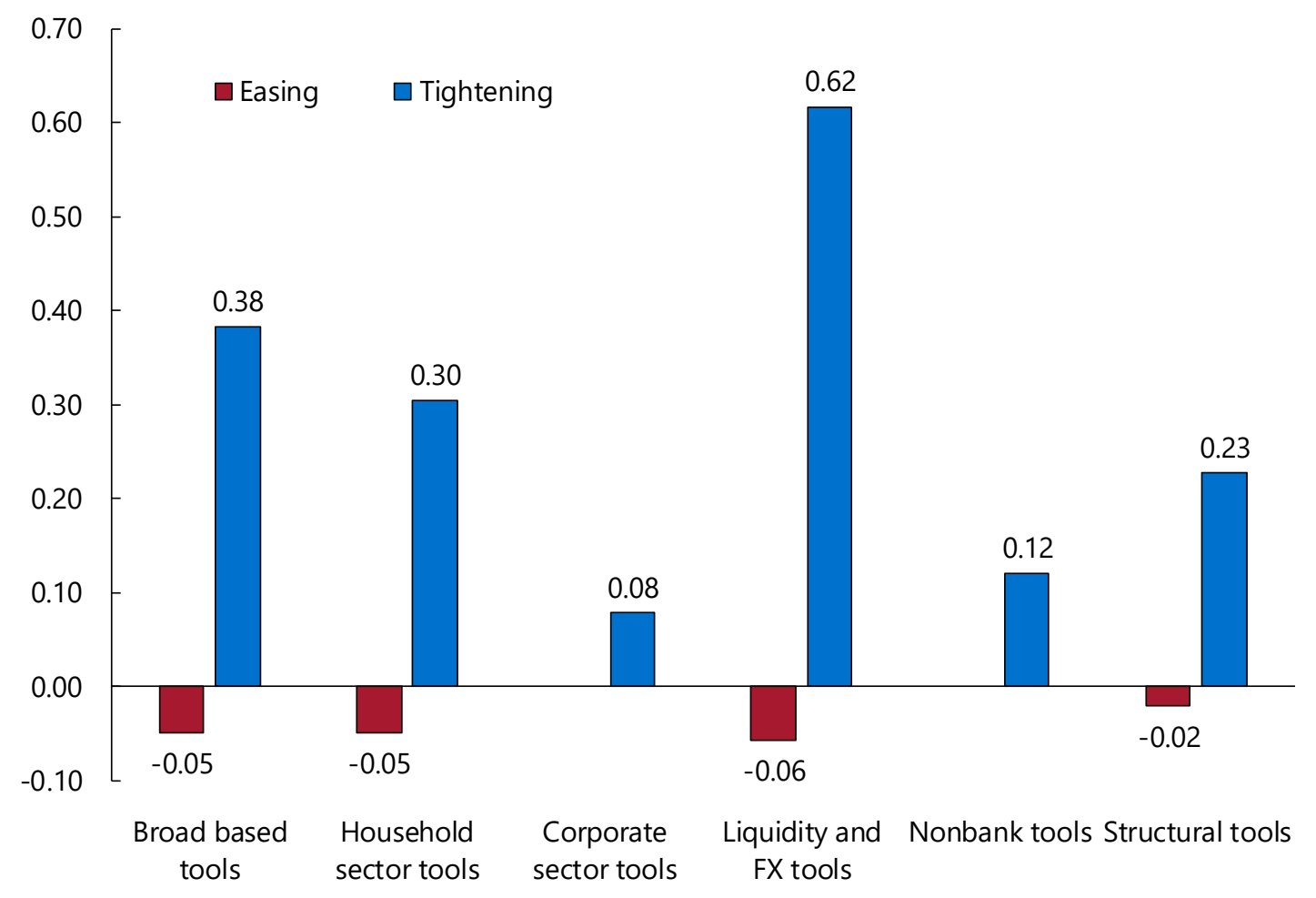

Average Number of Changes

(Per country)

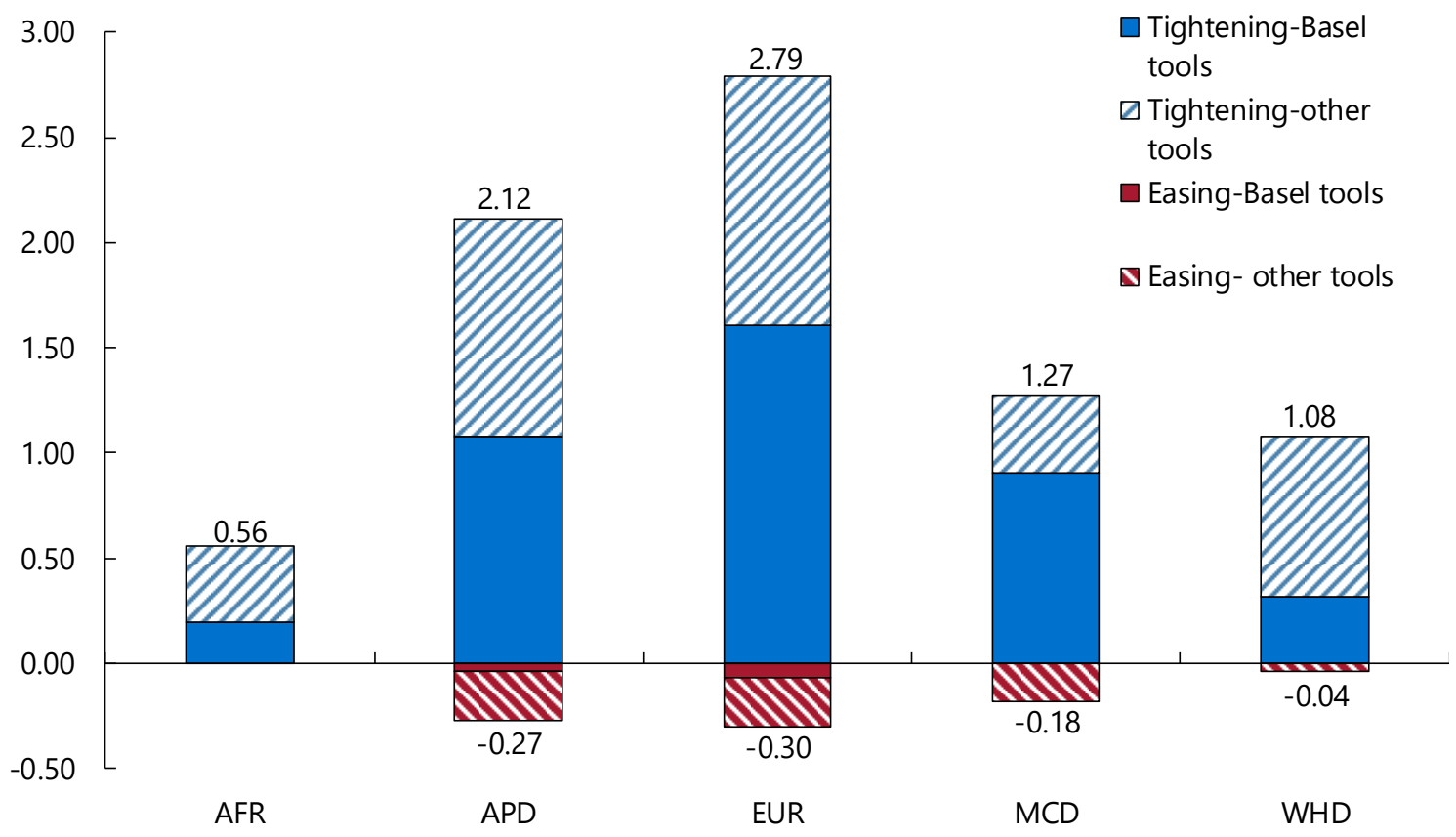

Sources: IMF Macroprudential Policy Survey, IMF staff estimates. 